\title{
GEOGRAPHICAL ASPECTS OF ENDOCRINE SYSTEM MORBIDITY OF POPULATION IN CHERNIHIV AND ZHYTOMYR REGIONS
}

\author{
${ }^{1}$ Tetyana SHOVKUN, ${ }^{2}$ Inna MYRON \\ 1,2Mykola Gogol State University of Nizhyn, Ukraine \\ 2miron1@ukr.net
}

\begin{abstract}
One of the main health effects of the Chernobyl accident are endocrine system diseases. The specific gravity of morbidity of endocrine system among the total population is $0.89 \%$ in Chernihiv region and $1.5 \%$ in Zhytomyr region that far exceeds the pre-accident values. This study makes comparative analysis of the dynamics of endocrine system diseases in the period from 1990 to 2014 in the areas officially regarded as contaminated by the Chernobyl accident and in the "clean" areas. A clear dependence between radiation contamination and increase in endocrine system morbidity was not ascertained. This shows the complex impact of various factors on endocrine health. In Ukraine, the prevalence of endocrine system diseases in 2014 was 8342.3 cases per 100 thousand people. In Chernihiv region, this index is higher than the average Ukrainian, but in Zhytomyr region it is slightly smaller. In terms of administrative raions high indexes of extension of endocrine diseases are typical both for "radioactive contaminated" and "clear" areas. Monitoring of endocrine health of population in radioactive contaminated areas should be done in the future to make an objective assessment of the health status and to identify the ways of its improvement.

Key words: radioactive contamination, endocrine system morbidity, prevalence of endocrine system diseases, endocrine health.
\end{abstract}

DOI: https://doi.org/10.17721/2413-7154/2016.76.44-49

UDC: 911.9:616.43 (477.51+477.42)

\section{ГЕОГРАФІЧНІ АСПЕКТИ ЗАХВОРЮВАНОСТІ ЕНДОКРИННОЇ СИСТЕМИ НАСЕЛЕННЯ В ЧЕРНІГІВСЬКІЙ ТА ЖИТОМИРСЬКІЙ ОБЛАСТЯХ}

\author{
'Тетяна ШОВКУН, ${ }^{2}$ Інна МИРОН \\ 1,2Ніжинський державний університет імені Миколи Гоголя, Україна \\ 2miron1@ukr.net
}

\begin{abstract}
Резюме: У статті зроблено аналіз динаміки захворюваності та поширення хвороб ендокринної системи населення за період з 1990 по 2014 роки в розрізі адміністративних районів Чернігівської та Житомирської областей, які офіційно визнані забрудненими внаслідок аварії на ЧАЕС. За цей період спостерігається значне підвищення рівня захворюваності ендокринної системи населення обох областей. У теж час прямої залежності між радіаційним забрудненням території та збільшенням захворюваності і поширенням хвороб ендокринної системи населення не визначено. Це свідчить про те, що крім радіаційного фактора на захворюваність ендокринної системи населення впливають і нерадіаційні фактори, які необхідно враховувати при інтерпретації отриманих результатів.
\end{abstract}

Ключові слова: радіоактивне забруднення, захворюваність ендокринної системи, поширеність хвороб ендокринної системи, ендокринне здоров'я населення.

DOI: https://doi.org/10.17721/2413-7154/2016.76.44-49

УдК: 911.9:616.43 (477.51+477.42)

Актуальність проблеми. Уже минуло майже 30 років із дня техногенної аварії на Чорнобильській АЕС. На фоні загальної стабілізації радіоекологічної ситуації в Україні відзначається тенденція до збільшення захворюваності на хвороби ендокринної системи населення. Території Чернігівської та Житомирської областей відносяться до областей України, які зазнали найбільшого радіоактивного забруднення. Нині люди, які проживають на радіаційнозабруднених територіях, отримують внутрішне випромінювання внаслідок споживання місцевих продуктів харчування. Тому вивчення радіоекологічної ситуації регіону та iï впливу на здоров'я населення залишається актуальним.

(C) Т. Шовкун, I. Мирон

Аналіз останніх публікацій. Аналіз останніх публікацій. Медико-географічні дослідження в Україні спрямовані переважно на розробку теоретико-методологічних основ медичної географiї. Це, насамперед, дослідження О. І. Шаблія, який визначив предмет вивчення медичної географії просторову структуру сфери здоров'я людини [7]. Л. Т. Шевчук, досліджуючи медико-соціальні аспекти використання трудового потенціалу, запропонувала модель регіонального аналізу і прогнозу медикосоціальних аспектів використання трудового потенціалу [8]. Вивчення теоретико-методологічних засад територіальної організації i комплексного пропорційного розвитку регіонального медичного комплексу на прикладі Вінницької області обгрунтовані в працях І.Мартусенко [2]. Вплив навколишнього природного середовища на здоров'я 
людини та територіальний розподіл поширеності та захворюваності хвороб різних класів відображений у працях Л. М. Нємець, Г.А.Баркова, К. А. Нємець, А. О. Корнус, О. Г. Корнус [1, 3]. Питання поширеності та захворюваності хвороб ендокринної системи населення вивчали В.І. Паньків, А. І. Томей та інші. Зокрема, В. І. Паньків дослідив стан ендокринологічної служби України та визначив перспективи розвитку медичної допомоги хворим 3 ендокринною патологією [4]. А. І. Томей зі співавторами здійснили оцінку динаміки розвитку ендокринних захворювань у дітей міста Ужгород [6]. Водночас територіальний розподіл поширеності та захворюваності хвороб ендокринної системи населення Чернігівської та Житомирської областей досліджено недостатньо.

Мета дослідження: проаналізувати рівень захворюваності ендокринної системи населення в Чернігівській та Житомирській областях за період 1990-2014 pр. 3 метою виявлення впливу на нього радіаційного чинника; визначити основні територіальні закономірності захворюваності ендокринної системи населення областей, що досліджуються.

Матеріали й методи досліджень. Дослідженням були охоплені адміністративні райони Житомирської та Чернігівської областей, щільність радіаційного забруднення яких $є$ найбільшою за рівнем та масштабами. Для реалізації поставленої мети використано літературні та інтернет-джерела, статистичні дані обласного інформаційноаналітичного центру медичної статистики Житомирської обласної ради та Чернігівського обласного управління статистики. При виконанні дослідження використано як загальнонаукові, так i географічні методи дослідження.

Виклад основного матеріалу. Внаслідок аварії на ЧАЕС радіоактивного забруднення зазнало 78 територій, із яких 73 райони і 5 міст обласного підпорядкування дванадцяти областей, зокрема Житомирської й Чернігівської областей. Населення цих областей отримало значну дозу зовнішнього радіаційного випромінювання, зокрема внаслідок випадання ізотопів радіоактивного йоду (переважно I-131). Одним із основних медичних наслідків аварії на ЧАЕС $€$ захворюваність ендокринної системи. Однак слід наголосити, що на формування ендокринного здоров'я населення впливають численні фактори - порушення обміну речовин, незбалансоване харчування, економічний рівень життя, психоемоційні та генетичні фактори. Систематичний вплив цих чинників знижує опірність організму, підвищує напруженість компенсаторних механізмів, що клінічно проявляється розвитком ендокринних захворювань $[4,6]$.

У структурі захворюваності населення Чернігівської області за класами хвороб у 2014 році значна питома вага належить хворобам органів дихання - 42,45\%, хворобам органів травлення $5,96 \%$, хворобам ока $-5,6 \%$ та хворобам системи кровообігу - 5,2\%. У структурі захворюваності населення Житомирської області у 2014 році також перше місце займають хвороби органів дихання, їх питома вага складає 42,9\%, друге місце належить хворобам сечостатевої системи із питомою вагою 7,9\%, третє - хворобам системи кровообігу, четверте - хворобам шкіри та підшкірної клітини, п’яте - інфекційним хворобам із питомою вагою 6,7\%, $5,4 \%$ i 4,3\% відповідно. Питома вага показника захворюваності ендокринної системи серед хвороб усього населення у Чернігівській області складає $0,89 \%$, у Житомирській області - 1,5\%. На перший погляд, даний показник є незначним, але у доаварійний період захворюваність ендокринної системи в областях була мінімальною і їі облік не проводився. На сьогодні відмічається сплеск захворюваності ендокринної системи у осіб, яким на момент аварії було менше 18 років. 3 метою виявлення впливу на захворюваність ендокринної системи радіаційного чинника проаналізуємо ㄲi динаміку за період 3 1990 по 2014 роки в адміністративних районах, які офіційно вважаються забрудненими внаслідок аварії на ЧАЕС, та в «радіаційно чистих» районах.

Динаміка показників захворюваність ендокринної системи населення у Чернігівській та Житомирській областях за період з 1990 по 2014 роки була неоднозначною. Попри певне очікування зростання даного показника відбулося не у всіх радіаційнозабруднених районах. Так, у Чернігівському районі Чернігівської області зафіксовано зменшення захворюваності ендокринної системи населення на 94 випадки на 100 тис. осіб, а у Народицькому районі Житомирської області - на 213 випадки на 100 тис. осіб. В інших радіаційнозабруднених районах цих областей показник захворюваності ендокринної системи населення зростав у різних діапазонах. Найбільше зростання даного показника відмічається у Корюківському районі Чернігівської області, Смільчинському та Лугинському районах Житомирської області - на 1400, 1073 і 1199 випадки на 100 тис. осіб відповідно. Водночас зростання показників захворюваність ендокринної системи населення характерно і для районів, які не належать до радіаційнозабруднених (таблиці 1, 2). У цілому захворюваність ендокринної системи населення за період, що досліджувався, змінювалася хвилеподібно, але в Чернігівській та Житомирській областях спостерігалась стійка тенденція до збільшення даного показника.

У середньому по Чернігівській області захворюваність ендокринної системи у 2014 році становила 701,7 випадків на 100 тис. осіб. Значне перевищення середньообласного показника фіксується у Корюківському та Ріпкинському районах - у 2,6 та 1,73 раза відповідно. Козелецький, Семенівський, Новгород-Сіверський райони мають показники, які наближені до середньообласного. Сосницький та Чернігівський райони характеризуються значно меншим показником захворюваності - у 2,95 та 1,8 раза менше за середньообласний. У той же час значні показники захворюваності відмічені у «радіаційночистих» районах. Серед них виділяється Менський район, де перевищення 
показника складає 1,8 раза. У Прилуцькому та Куликівському районах також зафіксовано перевищення показника у 1,4 та 1,3 раза. Показники захворюваності ендокринної системи населення в розрізі адміністративних районів Чернігівської області станом на 2014рік наведені у таблиці 1.

У середньому по Житомирській області показник захворюваності ендокринної системи у 2014 році становить 936,9 на 100 тис. осіб. Перевищення середньообласного показника відмічено у семи районах області та містах Житомирі та Коростені. Серед адміністративних районів перевищення середньообласного показника в 1,7 раза фіксується у Лугинському районі, в 1,6 раза - Черняхівському, в 1,4 раза - Житомирському та Смільчинському, в 1,3 раза - у Малинському, в 1,2 рази - у Любарському i в 1,06 раза - у Олевському районах. Ці райони (за винятком Черняхівського та Любарського) відносяться до таких, що найбільш постраждали у результаті аварії на ЧАЕС.

Наближений до середньообласного показник захворюваності ендокринної системи має Овруцький район - 905,5 на 100 тис. осіб. У той же час варто відмітити i райони, які зазнали значного впливу під час аварії на ЧАЕС, але у 2014 році мають показники захворюваності ендокринної системи нижчими за середньобласні. Це такі райони як Новоград-Волинський, Володимир-Волинський та Народицький. Їх показники $є$ меншими відповідно у $1,6,1,5,1,2$ раза. Показники захворюваності ендокринної системи населення в розрізі адміністративних районів Житомирської області станом на 2014рік наведені у таблиці 2.

Отже, як для Чернігівської, так і Житомирської областей значний показник захворюваності ендокринними хворобами населення характерний не лише для радіаційно-забруднених, а i для «радіаційно-чистих» районів. Чіткої залежності між радіаційним забрудненням території та збільшенням захворюваності ендокринної системи не встановлено. Це свідчить про комплексний вплив різних факторів на формування ендокринного здоров'я населення.

Важливим для аналізу стану ендокринного здоров'я населення є показник поширеності хвороби.

Динаміка показників захворюваності ендокринної системи населення в розрізі адміністративних районів Чернігівської області за період 1990-2014 рр. (на 100 тис. осіб) ${ }^{1}$

\begin{tabular}{|l|c|c|c|c|c|c|}
\hline \multirow{2}{*}{\multicolumn{1}{|c|}{ Райони }} & \multicolumn{5}{c|}{ Piк } \\
\cline { 2 - 7 } & 1990 & 2000 & 2002 & 2010 & 2014 & $1990 / 2014$ pp. \\
\hline Бахмацький & 360 & 401 & 345 & 362 & 415 & +55 \\
\hline Бобровицький & 293 & 956 & 317 & 496 & 563 & +270 \\
\hline Борзнянський & 250 & 919 & 329 & 391 & 391 & +141 \\
\hline Варвинський & 414 & 623 & 906 & 543 & 281 & -133 \\
\hline Городнянський & 437 & 211 & 361 & 676 & 730 & +293 \\
\hline Ічнянський & 776 & 223 & 173 & 178 & 491 & -285 \\
\hline Козелецький* & 659 & 744 & 189 & 519 & 698 & +39 \\
\hline Коропський & 144 & 1211 & 220 & 426 & 205 & +61 \\
\hline Корюківський & 425 & 1187 & 1132 & 1223 & 1825 & +1400 \\
\hline Куликівський & 154 & 423 & 262 & 848 & 903 & +749 \\
\hline Менський & 453 & 543 & 1178 & 920 & 1273 & +820 \\
\hline Ніжинський & 798 & 707 & 618 & 860 & 670 & -128 \\
\hline Н.-Сіверський & 545 & 792 & 728 & 791 & 797 & +252 \\
\hline Носівський & 191 & 498 & 710 & 132 & 557 & +366 \\
\hline Прилуцький & 640 & 529 & 697 & 701 & 991 & +351 \\
\hline Ріпкинський & 222 & 1768 & 1174 & 1411 & 1213 & +991 \\
\hline Семенівський & 351 & 567 & 402 & 308 & 552 & +201 \\
\hline Сосницький & 741 & 1650 & 1355 & 527 & 238 & +503 \\
\hline Срібнянський & 55 & 448 & 415 & 409 & 806 & +751 \\
\hline Талалаївський & 311 & 201 & 522 & 793 & 668 & +357 \\
\hline Чернігівський & 480 & 619 & 611 & 674 & 386 & -94 \\
\hline Щорський & 195 & 845 & 660 & 841 & 798 & +603 \\
\hline м. Ніжин & 311 & 529 & 537 & 341 & 736 & +425 \\
\hline м. Прилуки & 407 & 346 & 663 & 695 & 834 & +427 \\
\hline м. Чернігів & 175 & 947 & 846 & 665 & 604 & +429 \\
\hline
\end{tabular}

*шрифтом виділено радіаційно-забруднені райони

${ }_{1}^{1}$ таблиця складена за даними Чернігівського обласного управління статистики 
У Чернігівській області показник поширеності хвороб серед населення складав у 2010 році 197635,8 випадків на 100 тис. осіб, у 2014 - 201059,6 випадків на 100 тис. осіб, тобто зафіксовано збільшення даного показника на $0,85 \%$. У Житомирській області у 2010 році було зафіксовано 170105,4 випадків поширеності хвороб на 100 тис. осіб, у 2014 році даний показник збільшився до 173350,2 випадків на 100 тис. осіб, тобто його збільшення відбулося y $3,16 \%$.

В Україні показник поширеності хвороб ендокринної системи населення у 2014 склав 8342,3 випадків на 100 тис. осіб. У Чернігівській області цей показник $є$ вищим за середньоукраїнський i фіксується на рівні 9968,6 випадків на 100 тис. осіб. Для всіх семи радіаційно-забруднених районів області цей показник є більшим за середньообласний, зокрема для Семенівського району він становить 21288,7 випадків на 100 тис. осіб, Ріпкинського 18062, Козелецького - 15083,2; Новгород-Сіверського
- 14003,7; Корюківського - 13330,4. Дещо нижчі показники мають Сосницький i Чернігівський райони - 12096,3 та 12948,1 випадків на 100 тис. осіб відповідно (рис. 1). Але всі вони входять у десятку районів області 3 найвищим показником поширеності хвороби і перевищують середньообласний показник від 1,96 до 1,12 раза.

У Житомирській області показник поширеності хвороб ендокринної системи за даний період $\epsilon$ меншим за середньоукраїнський і складає 8194,5 випадків на 100 тис. осіб. Найбільші показники серед радіаційнозабруднених районів має Овруцький район. Показник поширеності хвороб ендокринної системи в ньому складає 17775,8 випадків на 100 тис. осіб і це у 2,16 раза є більшим за середньообласний. Друге місце посідає Лугинський район, у якому показник поширеності хвороб ендокринної системи становить 12656,1 випадків на 100 тис. осіб, що у 1,5 раза більше за середньообласний показник. Для п'яти радіаційно-

Таблиия 2

Динаміка захворюваності ендокринної системи населення в розрізі адміністративних районів Житомирської області за період 1990-2014 pр. (на 100 тис. осіб) ${ }^{2}$

\begin{tabular}{|c|c|c|c|c|c|c|}
\hline \multirow[b]{2}{*}{ Райони } & \multicolumn{6}{|c|}{ Рік } \\
\hline & 1990 & 2000 & 2002 & 2010 & 2014 & $1990 / 2014$ pp. \\
\hline Андрушівський & 434 & 844 & 825 & 1593 & 915 & +481 \\
\hline Баранівський & 374 & 694 & 304 & 738 & 365 & -9 \\
\hline Бердичівський & 413 & 748 & 851 & 842 & 492 & +79 \\
\hline Брусилівський & 74 & 823 & 270 & 392 & 484 & +410 \\
\hline Вол-Волинський & 497 & 737 & 534 & 580 & 698 & +201 \\
\hline Ємільчинський & 271 & 1661 & 1779 & 2107 & 1344 & +1073 \\
\hline Житомирський & 168 & 1386 & 1397 & 1687 & 1352 & +1184 \\
\hline Коростенський & 333 & 2002 & 1925 & 1203 & 765 & +432 \\
\hline Коростишівський & 314 & 481 & 585 & 997 & 590 & +276 \\
\hline Лугинський & 404 & 1674 & 1955 & 1827 & 1603 & +1199 \\
\hline Любарський & 346 & 391 & 512 & 1557 & 1135 & +789 \\
\hline Малинський & 412 & 1730 & 4245 & 1584 & 1237 & +825 \\
\hline Народицький & 825 & 2330 & 1923 & 751 & 612 & -213 \\
\hline Нов. - Волинський & 252 & 1076 & 1173 & 531 & 584 & +332 \\
\hline Овруцький & 565 & 2129 & 2764 & 1011 & 906 & +341 \\
\hline Олевський & 248 & 747 & 1583 & 1254 & 1001 & +753 \\
\hline Попільнянський & 379 & 691 & 430 & 465 & 676 & +297 \\
\hline Радомишльський & 411 & 1019 & 842 & 708 & 965 & +554 \\
\hline Романівський & 172 & 644 & 706 & 903 & 658 & +486 \\
\hline Ружинський & 539 & 319 & 379 & 607 & 768 & +229 \\
\hline Пулинський & 277 & 1017 & 949 & 778 & 570 & +293 \\
\hline Черняхівський & 344 & 1722 & 2045 & 1872 & 1518 & +1174 \\
\hline Чуднівський & 262 & 1445 & 1525 & 846 & 791 & +529 \\
\hline м. Бердичів & 259 & 1560 & 1358 & 1081 & 897 & +638 \\
\hline м. Житомир & 335 & 1015 & 1058 & 1111 & 1035 & +700 \\
\hline м. Коростень & 611 & 1355 & 1118 & 1328 & 1408 & +797 \\
\hline
\end{tabular}

*шрифтом виділено радіаційно-забруднені райони

\footnotetext{
2 таблиця складена за даними аналітично-інформаційного центру медичної статистики в Житомирській області
} 


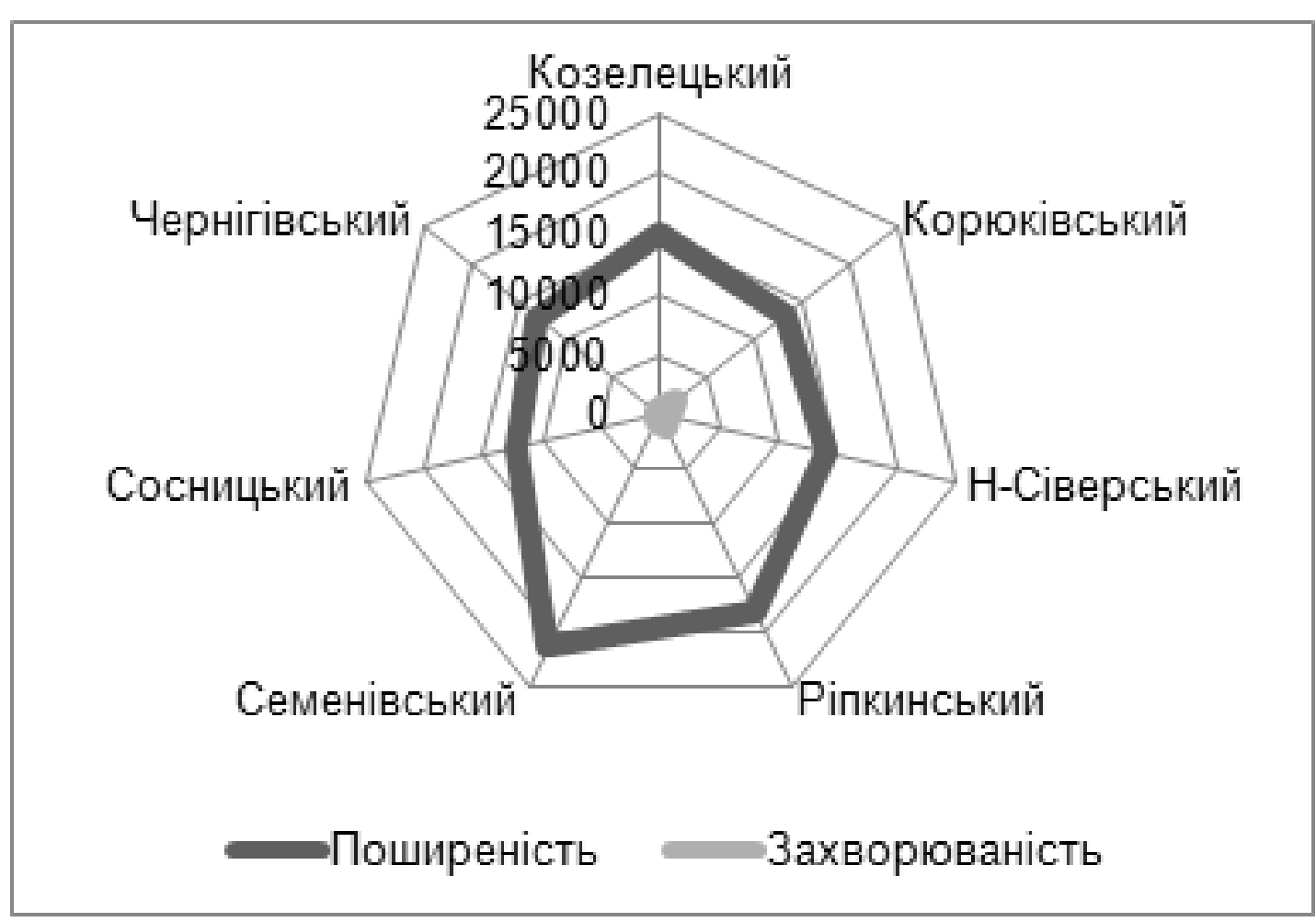

Рис. 1. Поширеність та захворюваність ендокринної системи населення у розрізі радіаційно-забруднених районів Чернігівської області у 2014 р. (100 тис. осіб) [5].

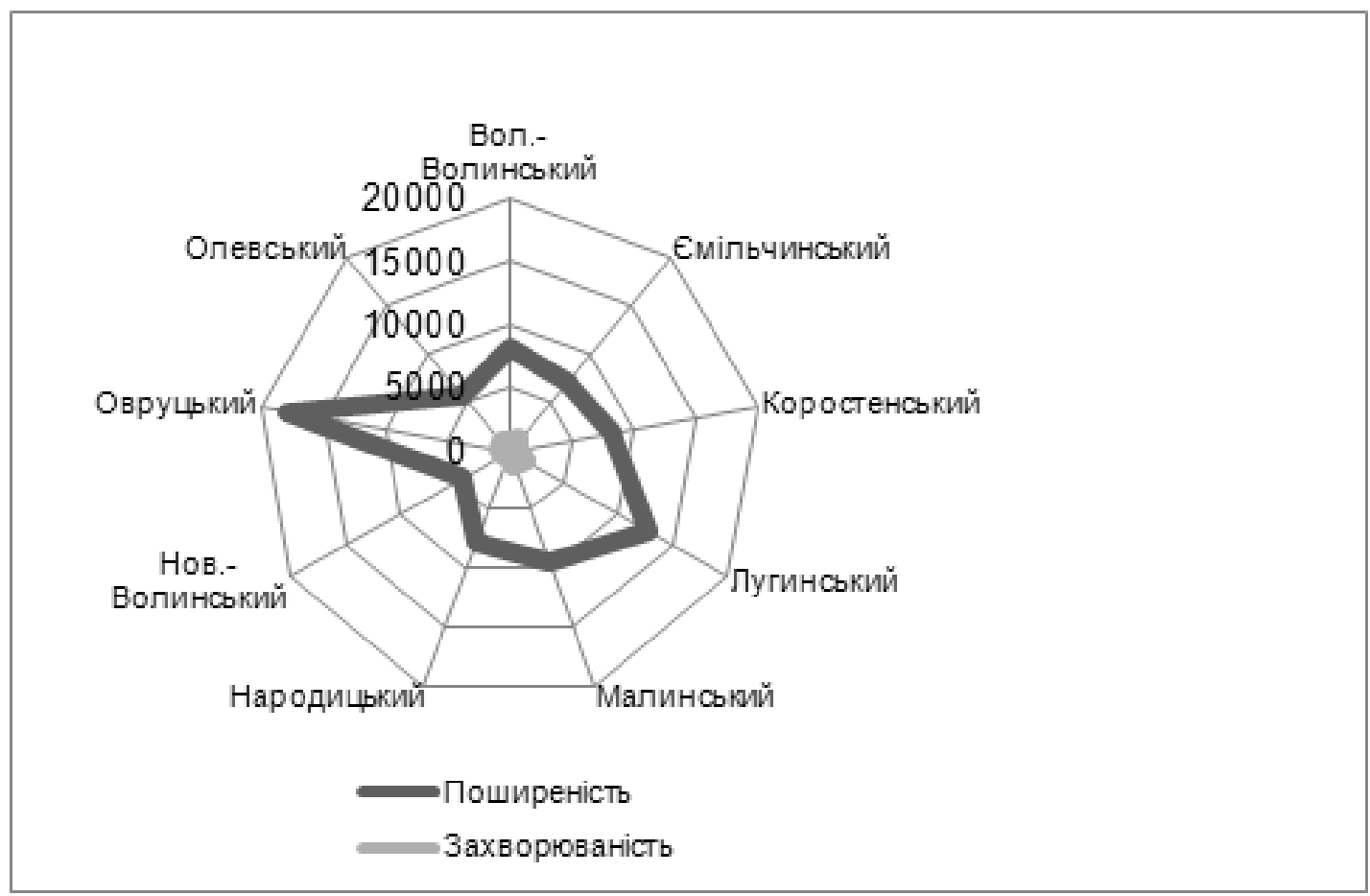

Рис. 2. Поширеність та захворюваність ендокринної системи населення у розрізі радіаційно-забруднених районів Житомирської області у 2014 р. (100 тис. осіб)

забруденних районів області цей показник $\epsilon$ наближеним до середньообласного. Так, у Малинському районі він становить 9434,2 випадків на 100 тис.осіб, у Володар-Волинському районі - 8077,2, у Коростенському - 8199,3, Народицькому - 7788,1, Ємільчинському - 7267,6. Серед радіаційно-забруднених районів найменші показники поширеності хвороб ендокринної системи відмічаються у Олевському та НовоградВолинському районах і становлять 5672,8 та 4159,0 випадків на 100 тис. осіб відповідно, що є меншим у 1,5 -1,97 раза за середньообласний показник (рис. 2.) У 1,4 раза відмічено перевищення показника поширеності хвороб ендокринної системи у Житомирському районі, який не відноситься до категорії найбільшого радіаційного забруднення 
внаслідок аварії на ЧАЕС. Отже, високі показники поширеності хвороб ендокринної системи характерні як для радіаційно-забрудненних, так і для «радіаційно-чистих» районів.

Проведений аналіз захворюваності та поширеності хвороб ендокринної системи населення в межах Чернігівської та Житомирської областей дозволяє зробити такі висновки:

1. Значне підвищення рівня захворюваності ендокринної системи населення Чернігівської та Житомирської областей спостерігається у постчорнобильський період, що свідчить про вплив радіаційного чинника на стан ендокринного здоров'я населення;
2. Чіткої залежності між радіаційним забрудненням території та збільшенням захворюваності та поширеності хвороб ендокринної системи населення не встановлено. Це дає можливість стверджувати, що крім радіаційного фактора на захворюваність ендокринної системи населення впливають i нерадіаційні фактори, які необхідно враховувати при інтерпретації отриманих результатів;

3. Моніторинг ендокринного здоров'я населення радіаційнозабруднених територій потрібно проводити i в майбутньому для здійснення об'єктивної оцінки стану здоров'я та визначення шляхів його поліпшення.

\section{References:}

1. Kornus O. G. et al. Sfera obslugovuvannâ naselennâ Sums 'koï oblastì: suspil'no-geografičnì aspekti [Service sector in Sumy region from the view of human geography], Kharkiv-Sumy, 2009, 228 pp. (In Ukrainian).

2. Martusenko İ. V. Rol' ekologìčnih faktorìv u formuvannì mediko-geografičnoï situaciï regìonu (na prikladì Vìnnic'koï oblastì) [Role of environmental factors in the development of medico-geographical situation of the region (the case of Vinnytsia oblast)]. In: Sučasnì problemi geoekologï ta racional'nogo prirodokoristuvannâ lìvoberežnoï Ukraïni: materiali Vseukraïns'koï naukovo-praktičnoï konferencï [Modern problems of geoecology and nature management of Left-Bank Ukraine: proceedings of Ukrainian scientific-practical conference]. Sumy, 2006, pp. 4751.

3. Nêmec' L. M., Barkova G. A., Nêmec' K. A. Medična galuz' Harkìvs 'koï oblastì: teritorial'nì osoblivostì, problemi ta šlâhi udoskonalennâ (suspil 'no-geografičnì aspekti) [Healthcare industry in Kharkiv oblast: regional peculiarities, problems and ways of improvement from the view of human geography], Kyiv, 2009 , 224 p. (In Ukrainian).

3. Pan'kìv V. Ì. Stan endokrinologičnoï službi Ukrä̈ni ta perspektivi rozvitku medičnö̈ dopomogi hvorim z endokrinnôu patologîêu [Endocrinology Service of Ukraine and prospects of development of medical care for patients with endocrine disorders]. Access mode: http://health-ua.com/articles/1342.html. Access date: 15.02.2016. (In Ukrainian).

4. Pokazniki stanu zdorov'â naselennâ, dîal'nostì ta resursnogo zabezpečennâ komunal'nih zakladìv ohoroni zdorov'â Černigivs 'koï oblastì za 2013-2014 roki [Indicators of population health status, activities and resource support for public health institutions in Chernihiv oblast in 2013-2014]. Ed.: M. V. Bovda. Chernihiv, 2015,256 p. (In Ukrainian).

5. Tomej A. İ., Peredrìj O. A., Ševerâ S. Û. Analìtična ocìnka dinamìki rozvitku endokrinnih zahvorûvan' u dìtej mista Užgorod [Analytical assessment of the endocrine disease dynamics in Uzhhorod children]. Problemi kliničnö̈ pediatrï [Issues of Clinical Pediatrics], 2011, N 3 (13), pp. 61-66. (In Ukrainian).

6. Šablìj O. Ì. Suspil'na geografîa: teoriâ, istorîa, ukrä̈noznavčì studiï [Human geography: theory, history, Ukrainistic studies], Lviv, 2001, 744 p. (In Ukrainian).

7. Ševčuk L. T. Mediko-social'nì aspekti vikoristannâ trudovogo potencialu: regional'nij analiz ì prognoz [Medical and social aspects of the labour potential use: regional analysis and forecast]. Lviv, 2003 , 490 p. (In Ukrainian). 